\title{
What to Do about Turnout Bias in American Elections? A Response to Wink and Weber
}

\section{Thomas L. Brunell}

At the end of the 2006 term, the U.S. Supreme Court handed down its decision with respect to the Texas redistricting controversy. While in its decision (LULAC v. Perry) the court struck down one of the newly drawn districts (the 23rd) the case is more notable for what the court did not do. The Court did not see anything in the Constitution indicating that state legislatures are restricted as to when redistricting ought to be done. Traditionally the process is done after the new census data is delivered, usually in years ending in 1 , and the new districts are in effect for elections in years ending in a 2. The state government in Texas was still divided in 2001 and a federal court ended up drawing new district boundaries, but after the GOP gained control in the next election they decided to redraw the congressional district lines more to their advantage for the 2004 election. Moreover a big part of the litigation was the claim that the Republicans had treated the Democrats unfairly enough in the new map that it constituted a partisan gerrymander and the Court, the Democrats claimed, ought to step in and doing something about it. The Justices did not strike down the map on these grounds and it is still unclear to most observers if the Court will step into the fray at some late date with respect to this issue.

Partisan gerrymandering is a problem because it introduces bias into the electoral system. Bias comes from a variety of sources: the geographic distribution of votes, turnout differences, population differences, registration differences, etc. The most noxious of these forms of bias is distributional bias, which is bias stemming from the geographic distribution of votes. This is how parties can rig the redistricting system so that one party can make an electoral system that lacks symmetry between the two parties. For instance if the Democrats are in control of drawing new lines they might draw something like the following:

$\begin{array}{ccc}\text { District } & \text { Percent Democratic } & \text { Percent Republican } \\ & 10 & 90 \\ 2 & 10 & 90\end{array}$

table continues

THOMAS L. BRUNELL is professor of political science in the School of Economic, Political and Policy Sciences at the University of Texas at Dallas.

The American Review of Politics, Vol. 27, Fall, 2006: 255-260

(c)2006 The American Review of Politics 


\begin{tabular}{ccc} 
District & Percent Democratic & Percent Republican \\
\hline 3 & 60 & 40 \\
4 & 60 & 40 \\
5 & 60 & 40
\end{tabular}

In this hypothetic state the Democrats only make up 40 percent of the total population, yet with artful map-making they can easily control 60 percent of the seats ( 3 of the 5). This is accomplished by "packing" Republicans into districts $1 \& 2$, then "cracking" them in districts 3, 4, and 5. So when a Republican is going to win a seat, you pack as many Republican voters in that district as possible to waste the votes (so that they cannot be used to win seats in surrounding districts). When the Democrats draw a seat for themselves it is also done in a way to waste even more Republican votes, so you want to win a district comfortably but still have a significant number of Republicans in the district (in this example 60 to 40). This bias then unfairly favors the Democrats at the expense of the Republicans based upon how the two parties' votes are distributed differently. This bias is important, a source of unfairness, and something that we should be worried about.

\section{Turnout Bias}

Wink and Weber (2005) examine the extent to which the Republicans are favored in state legislative elections around the country due to turnout related bias. Their approach is similar to the "cheap seats" approach taken by Campbell (1996) and somewhat akin to turnout related bias as described by Grofman, Koetzle, and Brunell (1997) and Brunell (1999). The method measures bias in an electoral system stemming from the differential levels of turnout across districts. Turnout related bias stems from the fact that some seats are won with significantly fewer votes than other seats. It is well known that turnout is related to economic and demographic factors and so is vote choice, so it is no surprise that turnout related bias almost always favors the Democrats. Which is to say, the seats that have the lowest turnout of voters are usually urban, inner-city districts and Democrats almost always win the elections, usually by very large margins. For instance, in 2004 Ralph Hall won the 4th district seat to the U.S. House of Representatives by garnering 182,866 votes, while Democrat Jim Nickerson only received 81,585 votes. So in this largely rural/suburban district there were over 260,000 votes cast. Meanwhile Democrat Gene Green was reelected to his seat in the 29th district with 78,256 votes with no Republican opponent. While both of these districts have the same underlying population (using 2000 Census data), if you just look at the number of votes that the Republican had to attract to get his seat compared to the number that the Democrat was elected with, one is 
tempted to conclude that there is something systematically unfair for the Republicans.

However, it is important to note that if turnout were higher in the low turnout districts virtually nothing would be different. The candidates who win in these districts are Democrats and the districts are overwhelmingly Democratic, so this bias has virtually no effect on aggregate election outcomes, which is why we should not be too worried about turnout related bias. However, Wink and Weber (2005) make several suggestions as to how to remedy bias stemming from turnout in state legislative elections and I will address each of these suggestions in turn.

The first suggestion involves drawing legislative district lines based on voters rather than based on raw population numbers. Currently any person who answers the census (citizen or not, voting age or not) is counted toward the total number of people needed in a state legislative or congressional district. We could change the number to just citizens, citizens of voting age, just voters, etc. While a case can be made for any of these options, I think it best if we stick with what we have. Most non-voters are still citizens and they all have a stake in public policy and they pay taxes. Moreover, restricting representation to only those people that vote is not particularly democratic in my mind. The bias toward voters is already evident in our public policy, should we make matters worse by disenfranchising non-voters even more formally?

Secondly, Wink and Weber suggest that reducing the size of some of the lower state legislative chambers across the country would alleviate some of the turnout bias. While decreasing the size of some state legislatures may have the effect of reducing turnout bias, most state legislative chambers are really not all that big to begin with and reducing their size to alleviate turnout bias (which really poses no problems to begin with) does not make much sense. There is a relationship between population of a country and the size of the national legislature called the "cube root law of assembly sizes" (see Taagapera and Shugart 1989, 173-83) which is fairly descriptive as the size of national assemblies tend to be roughly equal in size (number of seats) to the cube root of the population. Taagapera and Shugart (1989) also theorize as to why this empirical relationship exists which involves the number of legislators, the number of constituents, and the channels of communication between the two. They also show that this relationship is very strong for the size of assemblies throughout the world.

Figure 1 depicts the size of the lower chambers for 46 of the 50 states (the 4 largest states in terms of population were left off the graph to make it more readable) on the $y$-axis and the state population on the $x$-axis. The solid line depicts the cube root of the population. Virtually all of the states are below the line, indicating that the state legislative chamber is less than 
Figure 1. The "Cube Root Law for Assembly Size" Applied to the Lower Chambers of the U.S. State Legislatures

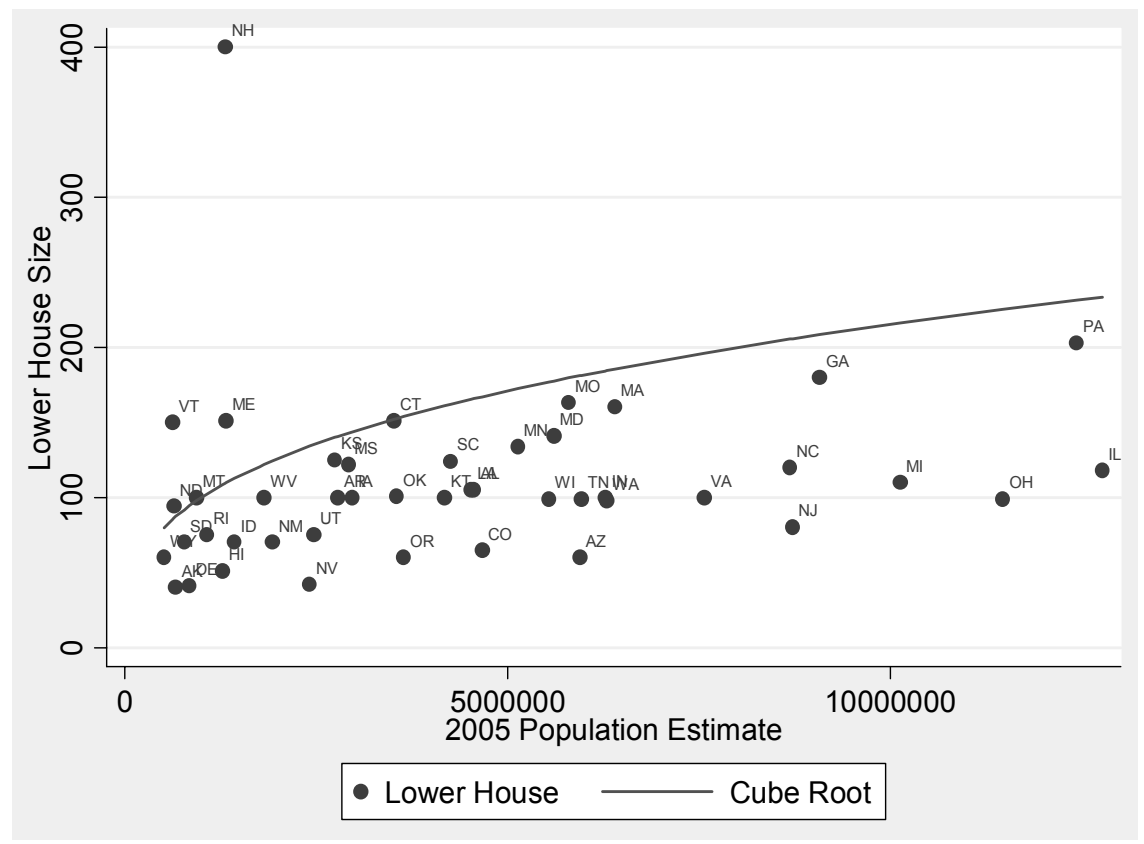

Note: To make the graph more readable the four largest states were not included. Notably all four of them are significantly below the cube root line. The four states with their respective lower chamber size in parentheses are: California (80), Texas (150), New York (150), and Florida (120).

the cube root of the population, although there are some states above the line. Most notably of course is New Hampshire with 400 seats in the lower chamber, but Vermont and Maine are also above the line. Thus, for all but a handful of states if anything they should probably be considering increasing the size of the legislative chamber and not decreasing it. There are two states (California and Texas) in which state legislative districts in the upper chambers (the state senates) are actually larger than districts for members of the U.S. House of Representatives from that state. The more constituents a legislator has to represent, ceteris paribus, the more difficult it is going to be to do a good job and represent these people well. Moreover, most, if not all, states will continue to grow in terms of absolute population, so a reduction in the size of these assemblies makes even less sense.

Wink and Weber next suggest that voter turnout be used along with other more traditional criteria link demographic and partisan factors in redrawing state legislative district lines. So districts would still be equally populous, but also drawn so that they are nearly equal in turnout as well. 
They write that: "such a remedy also has the added benefit of producing more diverse, heterogeneous districts" (Wink and Weber 2005, 319). Unfortunately, I have to disagree with Wink and Weber on this point as well, albeit from a somewhat different perspective. Elsewhere (Brunell 2006) I have argued against drawing competitive congressional (and state legislative) districts. In order for a district to be competitive there must be a diversity of opinion (rough parity between the two parties), but doing this has substantial costs (and really no benefits as it turns out). One of the major downsides to drawing competitive districts is that it maximizes the number of voters who vote for the losing candidate and do not care for their representatives. Elections decided by 1 vote yield the maximum number of dissatisfied voters. Competitive districts also make it impossible for the elected official to accurately translate the preferences of her constituents into votes in the assembly because the constituency does not agree on how she ought to vote. Rather than maximizing competition we should be maximizing the number of voters who will be well represented and make the business of representing voters easier by drawing electoral districts as ideologically homogeneous as possible. Moreover, by drawing all the districts in this manner we get outcomes in the aggregate that are proportion to the underlying partisanship of the state. In other words, the outcomes are fair to both parties. There may be less turnover in Congress this way, but if the outcomes are proportional then turnover is not particularly important. Drawing districts with an eye toward diversity and competition is something that ought not be done.

Concluding on a happy note-I completely agree with the final remedy that Wink and Weber suggest - we should try to increase voter turnout through a variety of methods like more mail-in balloting, voting on weekends, etc.

\section{Conclusion}

Partisan bias in electoral maps is a very serious concern and given the recent decisions by the Supreme Court in Pennsylvania (Vieth v. Jubelirer 541 U.S. 267 (2004)) and Texas (LULAC v. Perry 547 U.S. (2005)) it is clear that we cannot count on the courts to do anything about it. However, the real culprit to worry about is not turnout bias, but bias that stems from unequal distribution of the vote across districts (i.e., one party's votes are "packed" into some districts and "cracked" in others). The title of this article is in the form of a question: "What to do about turnout bias in American elections?" and for those who have taken the time to read what I have written, you deserve an answer-nothing. 


\section{REFERENCES}

Brunell, Thomas L. 2006. Rethinking Redistricting: How Drawing Uncompetitive Districts Eliminates Gerrymanders, Enhances Representation, and Improves Attitudes toward Congress. PS: Political Science and Politics 39:77-86.

Brunell, Thomas L. 1999. Partisan Bias in U.S. Congressional Elections, 1942-1996: Why the Senate is Usually More Republican than the House of Representatives. American Politics Quarterly 27:316-337.

Campbell, James E. 1996. Cheap Seats: The Democratic Party's Advantage in U.S. House Elections. Columbus: Ohio State University Press.

Grofman, Bernard, William Koetzle, and Thomas Brunell. 1997. An Integrated Perspective on the Three Potential Sources of Partisan Bias: Malapportionment, Turnout Differences, and the Geographic Distribution of Party Vote Shares. Electoral Studies 16:457-470.

Taagapera, Rein and Matthew Soberg Shugart. 1989. Seats \& Votes. New Haven, CT: Yale University Press.

Wink, Kenneth A., and Ronald E. Weber. 2005. Do Democrats and Republicans Pay the Same Price for Seats in the U.S. State Lower House Elections? An Analysis of "Cheap Seats" in Forty-four States. The American Review of Politics 26:305-322. 